\title{
ARAHAN PENGGUNAAN LAHAN SUB DAERAH ALIRAN SUNGAI (DAS) TELAGAWAJA PROVINSI BALI
}

\author{
Karsun $^{1)}$, I Nyoman Merit ${ }^{2)}$, I Wayan Suarna ${ }^{3)}$ \\ 1) Program Studi Magister Ilmu Lingkungan Universitas Udayana Bali \\ ${ }^{2)}$ Fakultas Pertanian Universitas Udayana Bali \\ 3) Fakultas Peternakan Universitas Udayana Bali \\ Email:bali_carson@yahoo.co.id
}

\begin{abstract}
Telagawaja Sub-Watershed is upper part watershed of Unda Watershed. As upper watershed, Telagawaja sub watershed has functions as conservation area, water catchment area, and managed in order to keep sub watershed environment not degradated.

This research objectives are to identify the characteristics of the land, the function of the area, and the erosion potential rate (TBE), as well as land management recommendations on Telagawaja Sub-Watershed. The identification of land is conducted by analyzing the characteristics of thematic maps in study area. The directives of classification land function is determined by the Minister of Agriculture Number.837/Kpts/Um/ 11/1980 and Number: 683/Kpts/Um/8/1981. The prediction of actual erosion is calculated by USLE formula for the agriculture area, while non-agricultural land use is applied Snyder formula (1980) in Asdak (2010). Erosion class and erosion rate (TBE) are determined based on the Director General of Reforestation and Land Rehabilitation Department of Forestry Number.041/Kpts/V/1998. Determination for the amount of erosion is still can be allowed using the method of Thompson (1957) in Arsyad (2010) which based on soil properties attached to Telagawaja sub watershed.

The research shows that Telagawaja Sub-Watershed characteristic is an area which is susceptible to erosion. The analysis shows that the direction of the area function Telagawaja sub-watershed consists of an area of $7337.28 \mathrm{Ha}$ of protection forest (66.01\%), and the function of a buffer area 3.778.31 Ha (33.99\%). The result of the study on Telagawaja sub-watershed erosion is 2777.07 tonnes ha $^{-1}$ year $^{-1}$. Erosion class and erosion rate of Telagawaja Sub-Watershed vary from very light to very severe. Erosion class and erosion rate (TBE) with category severe to very severe consist an area of $2.071,97$ ha $(18,64 \%)$ from total sub-watershed area. Land use planning implemented by applying alternative measures of soil and water conservation can reduce the rate of erosion of 2777.07 tonnes ha ${ }^{-1}$ year $^{-1}$ to 611.00 tonnes ha $^{-1} \mathrm{year}^{-1}$ or less 2166.07 tonnes ha ${ }^{1}$ year $^{-1}$.
\end{abstract}

Keywords : Land Characteristics; Area Functions; Erosion Hazards; Land Use Refferal.

\section{PENDAHULUAN}

Sub daerah aliran sungai (DAS) Telagawaja merupakan salah satu DAS yang ada di bagian hulu DAS Unda.Sub DAS adalah bagian DAS yang menerima air hujan dan mengalirkannya melalui anak sungai ke sungai utama(Kementerian Kehutanan, 2013). Sebagai hulu DAS, Sub DAS Telagawajaberfungsi sebagai daerah konservasi, tangkapan hujan dan dikelola untuk mempertahankan lingkungan DAS agar tidak terdegradasi (Effendi, 2007). Setiap DAS/Sub DAS memiliki karakter yang berbeda-beda, sehingga pengelolaannya pun berbeda antara satu DAS dengan DAS yang lainnya.Sehingga mengetahui karakter Sub DAS Telgawaja dalam hal ini dari aspek lahan merupakan hal yang sangat penting sebelum menyusun perencanaan penggunaan lahannya.

Pengelolaan lahan dimaksudkan agar lahan dapat berfungsi optimal sebagai media pengatur tata air dan produksi (Kartasapoetra, 1985) dan dapat menciptakan suatu keadaan yang mirip dengan keadaan alamiahnya (Arsyad, 2010). Pada kenyataannya, aktivitas pemanfaatan lahan mengakibatkan perubahan penggunaan lahan di wilayah Sub DAS Telagawaja.Penggunaan lahan (land use) merupakan bentuk intervensi (campurtangan) manusia terhadap lahan dalam rangka memenuhi kebutuhan hidupnya baik materiil maupun spiritual (Arsyad, 2010). Lahan yang diusahakan dengan cara-cara yang mengabaikan kaidah-kaidah konservasi tanah rentan terhadap erosi dan tanah longsor (Asdak, 2010).

Penelitian ini bertujuan untuk mengetahui karakteristik lahan, arahan klasifikasi fungsi kawasan, erosi dan tingkat bahaya erosi yang terjadi serta arahan penggunaan lahan guna Sub DAS Telagawaja. 


\section{METODE}

\subsection{Lokasi dan Waktu Penelitian}

Penelitian ini dilakukan Sub DAS Telagawaja. Waktu penelitian adalah Bulan Januari - Maret 2014.

\subsection{Bahan dan Alat}

Bahan yang digunakan dalam penelitian ini yaitu; data curah hujan 10 tahun terahir 2004-2013 di wilayah penelitian, Peta-peta Tematik pada lokasi penelitian yang berhubungan dengan tujuan penelitian seperti: Peta Jenis Tanah dan Kedalaman Tanah, Peta Rupa Bumi (RBI), Peta Kelerengan Lahan, Peta Bentuk Lahan, dan Peta Penutupan Lahan. Alat yang digunakan diantaranya GPS, kamera digital, alat tulis, ring sampel tanah, bor tanah, pisau, meteran, peralatan laboratorium tanah dan seperangkat komputer yang dilengkapi software ArcGIS versi 9.3 dan ArcView.

\subsection{Jenis dan Sumber Data}

Data yang digunakan adalah data primer dan data sekunder. Data primer merupakan data hasil observasi lapangan meliputi data penutupan vegetasi dan pengelolaan lahan serta data tanah. Data sekunder yang digunakan bersumber dari instansi/ dinasterkait antara lain data curah hujan, bukubukudan laporan-laporan hasil penelitian serta petapeta tematik lokasi penelitian yang berhubungan dengan tujuan penelitian.

\subsection{Prosedur Penelitian}

Prosedur penelitian ini diawali dengan membuat Peta Unit Lahan Sub DAS Telagawaja. Pembuatan peta unit lahan didasarkan atas peta kelerengan, peta geomorfologi (bentuk lahan), peta penutupan lahan Sub DAS Telagawaja serta peta administrasi. Survey pendahuluan dilakukan untuk mencocokan lokasi penelitian serta mengidentifikasi para pihak yang terkait untuk memperoleh data-data sekunder dan pendukung penelitian. Survey utama dilakukan untuk memperoleh data primer di lokasi penelitian seperti data penutupan vegetasi dan pengolahan lahan. Pengolahan dan analisis data serta penyusunan laporan hasil penelitian.

\subsection{Analisis Data}

Analisis data dilakukan beberapa tahap analisis. Output analisis dari masing-masing tahap akan menjadi indicator input dalam menanalisis arahan penggunaan lahan Sub DAS Telagawaja.

\subsubsection{Identifikasi Karakteristik Lahan}

Identifikasi karakteristik lahan Sub DAS Telagawaja menggunakan aplikasi GIS dengan menganalisis atribut yang terdapat peta-peta tematik yang digunakan untuk tujuan penelitian.

\subsubsection{Arahan Klasifikasi Fungsi Kawasan}

Analisis arahan klasifikasi fungsi kawasan Sub DAS Telagawaja didasarkan pada klasifikasi skor jenis tanah, intensitas hujan harian rata-rata dan kelerengan lahan sebagaimana Surat Keputusan Menteri Pertanian No.837/KPTS/Um/11/1980 Nomor: 683/Kpts/Um/8/1981.Ketiga faktor tersebut dinilai dengan sistem skoring kemudian dijumlahkan untuk menentukan klasifikasi fungsi kawasan. Kawasan adalah wilayah dengan kawasan lindung, kawasan penyangga, kawasan budidaya tanaman tahunan, kawasan tanaman semusim setahun dan kawasan pemukiman.

\subsubsection{Kelas dan Tingkat Bahaya Erosi}

Untuk memprediksi erosi di daerah pertanian menggunakan persamaan sesuai dengan rumus Universal Soil Loss Equation (USLE) yang dikembangkan oleh Wischmeier dan Smith (1978), dengan persamaan sebagai berikut:

$$
A=R K L S C P
$$

Pendugaan erosi pada daerah non pertanian (hutan) menggunakan persamaan USLE yang disempurnakan oleh Snyder (1980) dalam Asdak (2010) yaitu :

$$
A=R K L V M
$$

dimana:

$\mathrm{A}=$ Jumlah tanah yang hilang (ton hektar ${ }^{-1}$ tahun $^{-1}$ )

$\mathrm{R}=$ Indeks erosivitas hujan

$\mathrm{K}=$ Indeks erodibilitas tanah

$\mathrm{LS}=$ Indeks panjang dan kemiringan lereng

$\mathrm{C}=$ Indeks pengelolaan tanaman

$\mathrm{P}=$ Indeks upaya konservasi tanah

$\mathrm{VM}=$ Faktor konservasi tanah dan sistem pertanaman

Kelas dan Tingkat bahaya erosi (TBE) dihitung mengacu pada Keputusan Direktur Jenderal Reboisasi dan Rehabilitasi Lahan Departeman Kehutanan Nomor: 041/Kpts/V/1998 tanggal 21 April 1998 dengan membandingkan tingkat erosi di suatu lahan (land unit) dengan kedalaman tanah efektif pada satuan lahan tersebut.

Penentuan besarnya erosi yang masih dapat diperkenankan menggunakan metoda Thompson (1957) dalam Arsyad (2010) yang didasarkan pada sifat-sifat tanah yang ada di Sub DAS Telagawaja.

\subsubsection{Arahan Penggunaan Lahan Sub DAS Telagawaja}

Perencanaan arahan penggunaan lahan Sub DAS Telagawaja dibuat berdasarkan data keadaan lahan saat ini, kesesuaian fungsi kawasan dan tingkat bahaya erosi yang terjadi. Data tersebut diolah untuk menentukan alternatif arahan 
penggunaan lahan dan tindakan konservasi tanah dan air sehingga erosi tetap terkendali. Kisaran nilai prediksi erosi setelah perencanaan yang diinginkan adalah minimal sama atau di bawah nilai erosi yang ditoleransi.

\section{HASIL DAN PEMBAHASAN}

\subsection{Karakteristik Lahan Sub DAS Telagawaja}

Sub DAS Telagawaja secara geografis terletak diantara $08^{\circ} 16^{\prime} 49,481^{\prime \prime}$ - 08 $30^{\circ} 29,371^{\prime \prime}$ LS dan $115^{\circ} 23^{\prime} 30,81^{\prime \prime}$ - 115 $30^{\prime} 17,745^{\prime \prime}$ BT. Secara administratif wilayah Sub DAS Telagawaja teletak di tiga wilayah kabupaten, yaitu Kabupaten Bangli, Karangasem dan Klungkung dengan luas 11.115,59 hektar. Sebaran wilayah administrasi Sub DAS Telagawajadisajikan Tabel 1.

Tabel 1. Sebaran Wilayah Sub DAS Telagawaja.

\begin{tabular}{|c|c|c|c|}
\hline \multicolumn{2}{|c|}{ No Kabupaten/Kecamatan } & \multirow{2}{*}{$\begin{array}{c}\text { Desa } \\
3\end{array}$} & \multirow{2}{*}{$\begin{array}{c}\text { Luas (ha) } \\
4\end{array}$} \\
\hline 1 & 2 & & \\
\hline \multirow[t]{3}{*}{1} & Bangli/Kintamani & Abang Batu Dinding & 150,10 \\
\hline & & Abang Songan & 240,15 \\
\hline & & Suter & 735,03 \\
\hline \multirow[t]{11}{*}{2} & Karangasem/ & & \\
\hline & Rendang & Besakih & $2.807,33$ \\
\hline & & Menanga & $1.242,29$ \\
\hline & & Nongan & 332,84 \\
\hline & & Pempatan & $3.565,32$ \\
\hline & & Pesaban & 79,34 \\
\hline & & Rendang & 384,48 \\
\hline & Selat & Muncan & 243,26 \\
\hline & & Sebudi & 551,14 \\
\hline & & Sangkan Gunung & 477,03 \\
\hline & & Tangkup & 214,68 \\
\hline \multirow[t]{2}{*}{3} & Klungkung/Klungkung & Selat & 92,60 \\
\hline & Jumlah & $11.115,59$ & \\
\hline
\end{tabular}

Berdasarkan Tabel 1 diketahui bahwa luas sebaran luas wilayah Sub DAS Telagawaja Kabupaten Bangli di Kecamatan Kintamani seluas $1.125,28$ hektar $(10,12 \%)$, Karangasem di Kecamatan Rendang dan Selat seluas 9.897,71 hektar (89,04\%) dan Klungkung seluas 92,60 hektar (0,83 \%). Artinya Sub DAS Telagawaja merupakan DAS lintas wilayah kabupaten sehingga kewenangan pengelolaannya termasuk dalam DAS Provinsi.

Sub DAS Telagawaja merupakan daerah yang bertipe iklim sangat basah dengan curah hujan ratarata tahunan selama 10 tahun (tahun 2004-2013) antara 2.791 sampai dengan $3.628 \mathrm{~mm}_{\text {tahun }}{ }^{-1}$ dan hari hujan rata-rata sebanyak 96 sampai dengan 160 hari hujan. Banyaknya curah hujan yang terjadi perlu diwaspadai karena hujan memiliki daya perusak tanah yang merupakan pemicu terjadinya erosi tanah.
Terdapat 3 jenis tanah di Sub DAS Telagawaja yaitu Regosol berhumus seluas 2.612,51 hektar (23,50 \%), Regosol kelabu seluas 6.783,77 hektar (61,03\%) dan Regosol coklat kekuningan seluas 1.719,31 hektar (15,47\%). Tanah regosol merupakan tanah dengan kandungan bahan organik yang rendah, selain itu tanah ini juga peka terhadap erosi.Berdasarkan genesis/asal-usulnya bentuk lahan yang dapat dijumpai pada Sub DAS Telagawaja meliputi bentuk lahan asal proses vulkanik seluas 10.431,86 hektar $(93,85 \%)$ dan denudasional seluas 683,73 hektar $(6,15 \%)$. Adanya bentuk lahan denudasional menunjukan adanya proses erosi yang sedang dan telah terjadi. Dari penelitian Coster 1938 dalam Arsyad (2010) menunjukan bahwa tanah Regosol dari bahan vulkan merupakan tanah yang memiliki sifat sangat rentan terhadap erosi.

Kemiringan lahan pada Sub DAS Telagawaja secara berurutan adalah wilayah landai seluas $3.414,01$ hektar $(30,71 \%)$, agak curam seluas 4.364,63 hektar (39,27\%), curam seluas 3.179,02 hektar $(28,60 \%)$ dan sangat curam seluas 157, 93 hektar (1,42 \%). Kondisi topografi ini menunjukan bahwa wilayah Sub DAS Telagawaja merupakan wilayah dengan bentuk topografi bergelombang, berbukit hingga bergunung. Arsyad (2010) menyatakan lereng yang semakin curam atau panjang akan meningkatkan besarnya erosi. Jika lereng semakin curam maka kecepatan aliran permukaan meningkat sehingga kapasitas daya angkut meningkat. Lereng yang semakin panjang, berarti volume air yang mengalir semakin besar. Sehingga kecepatan aliran juga semakin besar dan benda yang bisa diangkut akan semakin banyak.

Penutupan vegetasi di dalam kawasan hutan terdiri atas hutan dengan vegetasi penutupan rapat seluas 3.854,04 hektar (34,67\%), hutan dengan vegetasi penutupan sedang seluas 956,85 hektar (8,61\%), semak belukar 577,22 hektar (5,19\%) dan tanah terbuka seluas 157,93 hektar atau 1,42\% dari total DASnya. Penutupan lahan di luar kawasan hutan terdiri atas kebun campuran rapat seluas 2.433,71 hektar (21,89\%), kebun campuran sedang $1.255,06$ hektar $(11,29 \%)$, kebun campuran jarang 247,91 hektar (2,23\%), tegalan 1.225,05 hektar (11,02\%), permukiman 55,75 hektar $(0,5 \%)$ dan sawah seluas 352,07 hektar atau 3,17\% dari total DASnya. Adanya variasi penutupan lahan ini menunjukkan adanya intervensi manusia terhadap lahan di wilayah Sub DAS Telagawaja.

Erosi tanah merupakan fungsi dari iklim, jenis tanah, topografi dan tindakan manusia. Banyaknya curah hujan yang jatuh di wilayah Sub DAS Telagawaja, didukung dengan jenis tanah yang mudah tererosi dimana bentuk topografi didominasi oleh topografi berbukit hingga bergungung serta adanya intervensi manusia di dalam mengelola lahannya maka wilayah Sub DAS Telagawaja 
merupakan wilayah yang rentan terhadap terjadinya erosi tanah. Kondisi tersebut apabila lahan tidak dikelola dan direncanakan dengan baik bisa berdampak buruk terhadap lahan Sub DAS Telagawaja yang merupakan daerah konservasi.

\subsection{Arahan Klasifikasi Fungsi Kawasan Sub DAS Telagawaja}

Upaya penyelamatan lahan Sub DAS Telagawaja perlu segera dilakukan baik secara makro maupun mikro. Penyelamatan lahan secara makro dilakukan dengan cara penataan lahan pada wilayah Sub DAS Telagawaja sesuai dengan arahan fungsi utamanya yaitu sebagai fungsi lindung dan produksi. Upaya ini untuk menjaga keseimbangan antara kemampuan lahan dengan jenis pemanfaatan yang digunakan sebagai upaya untuk melindungi kelangsungan fungsi dan manfaat sumberdaya lahan di Sub DAS Telagawaja.

Berdasarkan analisis yang dilakukan, peruntukan wilayah Sub DAS Telagawaja terdiri atas kawasan lindung dan kawasan penyangga. Luas wilayah lindung mencapai 7.337,28 hektar atau $66,01 \%$ dari luas total DASnya. Sedangkan wilayah penyangga di Sub DAS Telagawaja seluas 3.778,31 hektar atau 33,99\% dari luas DASnya.

Penggunaan lahan yang diperbolehkan pada kawasan lindung adalah pengolahan lahan dengan tanpa pengolahan tanah (zero tillage) dan dilarang melakukan penebangan vegetasi hutan. Pemanfaatan kawasan lindung ini bisa dimanfaatkan untuk pemanfaatan kawasan berupa jasa lingkungan dan pemungutan hasil hutan bukan kayu.

Daerah penyangga merupakan daerah yang mengelilingi kawasan lindung yang berfungsi membatasi aktifitas manusia di dalam kawasan lindung agar tidak merusak kawasan lindung (Soemarwoto, 1985).Kawasan penyangga ini merupakan batas antara kawasan lindung dan kawasan budidaya. Pemanfaatan lahan pada wilayah ini berpengaruh terhadap kelestarian kawasan lindung yang ada di wilayah Sub DAS Telagawaja.

\subsection{Kelas dan Tingkat Bahaya Erosi}

Penggunaan lahan secara tepat guna dan berhasil guna hanya akan terjadi bila dilakukan berdasarkan kemampuan alami yang dimiliki oleh lahan itu sendiri. Kesalahan dalam mengelola atau salah dalam pemanfaatannya merupakan penyebab timbulnya kerusakan lahan (Rahim, 2006). Saat ini, penggunaan kawasan lindung maupun kawasan dengan fungsi penyangga di wilayah Sub DAS Telagawaja tidak semuanya sesuai dengan pemanfaatan sebagaimana seharusnya. Aktivitas ini tentunya memicu dan mempercepat terjadinya erosi tanah di wilayah Sub DAS Telagawaja yang secara karakteristik lahannya merupakan lahan yang rentan terjadi erosi.
Hasil analisis terhadap prediksi erosi di wilayah Sub DAS Telagawaja, menunjukan erosi yang terjadi di Sub DAS Telagawaja sebesar 275.361,49 ton tahun ${ }^{1}$ atau $2.777,07$ ton hektar ${ }^{-1}$ tahun $^{-1}$. Hal yang menarik dari penelitian ini adalah bahwa erosi tidak hanya terjadi di lahan dengan fungsi penyangga (budidaya) tetapi pada lahan dengan fungsi lindung, bahkan lebih besar. Besarnya erosi pada lahan dengan fungsi lindung sebesar 1.611,99 ton hektar ${ }^{-1}$ tahun $^{-1}$ atau $58,05 \%$ lebih besar dari kawasan penyangga yang hanya $41,95 \%$ atau sebesar $1.165,09$ ton hektar ${ }^{-1}$ tahun $^{-1}$. Menariknya lagi dari jumlah erosi yang terjadi dalam kawasan lindung,sebesar 86,03\% dari erosi yang terjadi atau 1.386,79 ton hektar-1 tahun $^{-1}$ terjadi pada kawasan lindung di luar kawasan hutan (lahan budidaya) atau menyumbang 49,94\% dari total erosi yang terjadi sementara luasnya hanya 1.791,24 atau $16,12 \%$ dari total luas DAS. Kondisi tersebut perlu diwaspadai dan perlu mendapat perhatian serius mengingat kawasan lindung merupakan kawasan yang ditetapkan dengan fungsi utama melindungi kelestarian lingkungan hidup yang mencakup sumberdaya alam, sumberdaya buatan, dan nilai sejarah serta budaya bangsa guna kepentingan pembangunan berkelanjutan.

Besarnya nilai erosi yang terjadi selanjutnya digunakan untuk menentukan kelas erosi dan tingkat bahaya erosi di wilayah Sub DAS Telagawaja. Kelas erosi yang terjadi di Sub DAS Telagawaja bervariasi dari kelas I sampai dengan kelas III. Secara umum erosi pada kelas III terjadi di Desa Besakih, Menanga, Rendang, Pesaban, Sebudi, Muncan, dan sangkan Gunung. Penggunaan lahan pada kelas ini merupakan lahan kebun campuran dan tegalan. Erosi pada pada kelas II hampir terjadi di seluruh wilayah kecuali Desa Rendang, Pesaban dan Muncan. Luas per masing-masing kelas erosi dari tingkat I sampai dengan kelas III secara berurut adalah kelas I seluas 6.328,79 hektar atau 56,94\%, erosi kelas II seluas 3.540,47 hektar atau 31,85\% dan erosi kelas III seluas 1.246,33 hektar atau 11,21\%.

Tingkat bahaya erosi (TBE) diperoleh dengan membandingkan besarnya erosi yang terjadi (erosi aktual) dengan kedalaman efektif tanah pada satuan unit lahan di wilayah bersangkutan. Hasil analisis TBE pada Sub DAS Telagawaja bervariasi dari tingkat sangat ringan sampai dengan tingkat sangat berat. TBE pada Sub DAS Telagawaja secara berturut disajikan sebagai berikut: tingkat sangat ringan (SR) seluas 1.648,31 hektar atau 14,83\%, ringan (R) seluas 2.331,29 hektar atau 20,97\%, sedang (S) seluas 5.064,02 hektar atau 45,56\%, berat (B) seluas $1.432,95$ hektar atau $12,89 \%$ dan sangat berat (SB) seluas 639,02 hektar atau 5,75\%.

Secara umum erosi tanah yang berat sampai sangat berat, terjadi pada lahan dengan tutupan lahan berupa vegetasi tetap dengan dengan persen penutupan penutupan tanah adalah semak belukar rendah dengan tajuk daun lebar atau seresah belum 
membusuk sebesar $80 \%$ dan tajuk tanaman bawah sebesar $25 \%$, hutan lindung dengan luas penutupan tajuk kurang dari $20 \%$, kebun campuran jarang sampai sedang dan tanaman semusim, jenis tanah regosol serta kemiringan lereng antara 15\% sampai lebih dari $>40 \%$ dengan pengolahan lahan berupa teras tradisional sampai teras bangku dengan konstruksi sedang. Erosi tanah yang sangat ringan terjadi pada vegetasi tetap rapat dan kebun campuran rapat dengan pengolahan lahan berupa teras bangku dengan konstruksi sedang hingga baik.

Mengacu pada peta kedalaman tanah, wilayah Sub DAS Telagawaja terdiri atas kedalam tanah < $30 \mathrm{~cm}$, kedalaman $30-60 \mathrm{~cm}$ dan kedalaman $>90$ $\mathrm{cm}$. Dengan menggunakan Kriteria yang digunakan oleh Thomson (1957) dalam Arsyad (2010) maka secara teoritis erosi yang diperbolehkan (Edp) untuk tanah dengan kedalaman < $30 \mathrm{~cm}$ erosi yang diperbolehkan tidak boleh lebih dari 0,8 mm tahun ${ }^{-1}$ atau 9,6 ton hektar ${ }^{-1}$ tahun $^{-1}$, nilai Edp untuk tanah dengan kedalaman $30-60 \mathrm{~cm}$ sebesar $1,2 \mathrm{~mm}$ tahun ${ }^{1}$ atau 14,4 ton hektar ${ }^{-1}$ tahun $^{-1}$ sementara untuk tanah dalam dengan kedalaman $>90 \mathrm{~cm}$ dengan lapisan bawah berpermeabilitas tinggi di atas substrata yang telah melapuk adalah sebesar 2,5 mm tahun ${ }^{-1}$ atau 30 ton hektar ${ }^{-1}$ tahun $^{-1}$.

Besarnya erosi aktual yang terjadi pada Sub DAS Telagawaja secara umum telah melebihi batas erosi yang ditoleransi. Wilayah desa dimana erosi aktualnya telah melebihi erosi yang ditoleransi meliputi Desa Besakih, Menangan, Rendang, Nongan, Pesaban, Sebudi, Muncan, Sangkan Gunung, Tangkup dan Desa selat. Ini memberikan pesan bahwa penutupan vegetasi, pola tanam dan tindakan konsevasi tanah yang ada di wilayah tersebut belum mampu untuk mencegah atau menekan terjadinya erosi sampai pada tingkat yang tidak membahayakan. Hal ini kalau dibiarkan dapat berdampak buruk terhadap lahan Sub DAS Telagawaja yang bisa mengakibatkan timbulnya lahan tidak produktif atau lahan kritis dimana erosi sebagai salah satu indikatornya. Atas kondisi tersebut diperlukan upaya penyelamatan lahan secara mikro berupa arahan penggunaan lahan Sub DAS Telagawaja.

\subsection{Arahan Penggunaan Lahan}

Penyelamatan lahan secara mikro dilakukan dengan menerapkan alternatif tindakan konservasi tanah dan air pada wilayah Sub DAS Telagawaja sebagai upaya untuk menekan atau mengendalikan erosi.Pengendaliaan laju erosi sehingga sama atau lebih kecil dari erosi yang diperbolehkan diperlukan arahan penggunaan lahan berupa pemilihan tanaman/pola tanam (faktor C) dan tindakan konservasi tanah (faktor P) yang mempunyai nilai sama atau lebih kecil dari nilai CP maksimum. Hal ini dilakukan mengingat faktor-faktor lain, yaitu $R$ (erosivitas hujan), K (erodibilitas tanah), LS (faktor lereng) sulit dirubah.

Perencanaan arahan penggunaan lahan Sub DAS Telagawaja merupakan upaya penanganan lahan Sub DAS Telagawaja secara sistematis menggunakan akal sehat dan usaha keras yang berkesinambungan sehingga pemanfaatan lahan dapat berlangsung secara terus-menerus produktif. Perencanaan arahan penggunaan lahan pada Sub DAS Telagawaja didasarkan pada kodisi fisik lahan saat ini, arahan klasifikasi fungsi kawasan, prediksi erosi dan tingkat bahaya erosi yang terjadi dengan cara mengoreksi faktor penutupan vegetasi (C), faktor pengelolaan lahan $(\mathrm{P})$ serta faktor konservasi tanah dan sistem pertanaman (VM).

Aktivitas pengelolaan sumber daya lahan dengan menerapkan alternatif penerapan teknik konservasi tanah dan air dilakukan dengan cara menambah vegetasi penutupan lahan dan memperbaiki praktek pengelolaan lahan di masing-masing unit lahan. Penerapan arahan penggunaan lahan tidak hanya menekan laju erosi yang terjadi tetapi mampu mengurangi tingkat bahaya erosi yang terjadi di Sub DAS Telagawaja. Besarnya laju erosi yang berhasil ditekan sebesar 2.166,07 ton hektar ${ }^{-1}$ tahun $^{-1}$ (78,00\%) dari erosi yang terjadi sebesar 2.777,07 ton hektar ${ }^{-1}$ tahun $^{-1}$ menjadi 611,00 ton hektar ${ }^{-1}$ tahun $^{-1}$.

\section{SIMPULAN DAN SARAN}

\subsection{Simpulan}

1. Karakteristik lahan Sub DAS Telagawaja merupakan lahan yang rentan terhadap terjadinya erosi tanah.

2. Berdasarkan fungsi utamanya, wilayah Sub DAS Telagawaja merupakan kawasan lindung dan kawasan penyangga.

3. Tingkat bahaya erosi yang terjadi di wilayah Sub DAS Telagawaja bervariasi dari sangat ringan hingga sangat berat.

4. Arahan penggunaan lahan dengan Penerapan alternatif teknik konservasi tanah dan air yang sesuai mampu menekan tingkat bahaya erosi di wilayah Sub DAS Telagawaja

\subsection{Saran}

1. Mengingat karakteristik lahan Sub DAS Telagawaja yang rentan terhadap erosi maka disarankan agar dalam pengelolaannya harus benar-benar memperhatikan teknik konservasi tanah dan air yang memadai.

2. Agar dilakukan sosialisasi dan penyuluhan sebagai upaya peningkatan sumberdaya masyarakat kaitannya dengan pemahaman akan fungsi dan manfaat kawasan lindung dan penyangga serta upaya penegakan aturan bagi yang melanggarnya. 
3. Erosi yang terjadi sudah pada tingkat yang membayakan sehingga perlu dilakukan upaya pemilihan pola tanam dan teknik pengelolaan lahan yang baik terutama pada lahan yang tingkat erosinya sudah melebihi erosi yang diperkenankan.

4. Arahan penggunaan lahan dilakukan dengan menambah penutupan vegetasi dan pemilihan pola tanam dan pengelolaan lahan disarankan agar memilih jenis-jenis tanaman yang sudah tumbuh baik di lokasi penelitian, terjangkau oleh masyarakat serta memiliki nilai ekonomi yang baik.

\section{DAFTAR PUSTAKA}

Arsyad, S. 2010. Konservasi Tanah \& Air. Edisi Kedua. Bogor : IPB Press.

Asdak, C. 2010. Hidrologi dan Pengelolaan Daerah Aliran Sungai. Edisi kelima. Yogyakarta : Gadjah Mada University Press.
Effendi, E. 2007. Kajian Model Pengelolaan Daerah Aliran Sungai (DAS) Terpadu. (cited 2013 Des.3). Published by Andi Prasetyo.Available from: http://www.scribd.com/doc/52831935

Kartasapoetra, G. A. G. 1985. Teknologi Konservasi Tanah dan Air. Jakarta : Rineka Cipta.

Kementerian Kehutanan. 2013. Keputusan Direktur Jenderal Bina pengelolaan Daerah Aliran Sungai Kementerian Kehutanan Nomor: P.3/Kpts-II/ 2013 tentang Pedoman Identifikasi Karekteristik DAS. Jakarta: Kementerian Kehutanan RI.

Rahim, S.E. 2006. Pengendalian Erosi Tanah Dalam Rangka Pelestarian Lingkungan Hidup. Cetakan Pertama. Jakarta : PT. Bumi Aksara.

Soemarwoto, Otto. 1985. Ekologi, Lingkungan Hidup dan Pembangunan. Jakarta: Djambatan.

Wischmeier, W. H., Smith, D. D. 1978. Predicting Rainfall Erosion Losses - A Guide to Conservation Planning. Washington DC: US Gov. US Dep. of Agriculture, Agric. Print Off. Handbook No. 537. 